\title{
ANALISIS SUB SEKTOR UNGGULAN YANG BERDAYA SAING PADA SEKTOR PERTANIAN DI KABUPATEN LANGKAT
}

\author{
Muhammad Rif'an Harahap \\ Program Pasca Sarjana Universitas Negeri Medan \\ Jl. Williem Iskandar Ps. V Medan 20221, Telp. 061-6613365 \\ E-mail : rifanharahap@yahoo.co.id
}

\begin{abstract}
System changes from centralized to decentral ized governance has provided an opportunity for local governments to regulate and manage Natural Resources (NR) and Human Resources (HR) in the region to create a welfare society can be characterized by the growth of regional economic growth. In order to achieve a prosperous economy, there needs to be planning that begins with recognizing the potential possessed by Langkat Regency so that planning can be prepared well so the regional economic development goals can be achieved. The research was conducted to determine the contribution and sub-sectors growth in the agricultural sector and a base and competitive sub-sectors so that it can be seen the leading subsectors of agriculture. The analysis method used is descriptive analysis will illustrate how the rate of growth and the contribution of sub-sectors in the agricultural sector. Location Quetiont (LQ) Analysis was used to determine the base and non-base sub-sector. While the analysis of Revealed Comparative Advantage (RCA) is used to see the sub-sector competitiveness. The combination of $L Q$ and $R C A$ analysis can then be used to determine the leading sub-sector. From the analysis it is known that sub-sector of the agricultural sector is a base sub-sector which has the potential to become the leading sub-sector.
\end{abstract}

Keywords:: quality sector, Agriculture, $L Q, R C R$

\section{PENDAHULUAN}

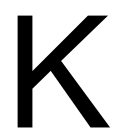

abupaten Langkat merupakan salah satu kabupaten terluas di wilayah Pantai Timur Propinsi Sumatera Utara yaitu sekitar 6.263,29 $\mathrm{km}^{2}$ atau 8,74 persen dari total luas Sumatera Utara. Luasnya kabupaten ini menjadikan beranekaragam pula kondisi topografi daerahnya yang terdiri dari daerah dataran rendah, kepulauan, tepi pantai dan perbukitan sehingga memiliki potensi sumber daya alam yang perlu digali.

Pertumbuhan ekonomi Kabupaten Langkat sangat dipengaruhi oleh sektor pertanian yang memiliki kontribusi lebih dari 50 persen dalam pembentukan

QE Journal |Vol.02 - No.03 - 18 
PDRB-nya, dimana sub sektor tanaman bahan makanan dan tanaman perkebunan memiliki peran besar dalam pembentukan NTB (Nilai Tambah Bruto) sektor pertanian ini.

Dengan kondisi di atas dan luasnya Kabupaten Langkat serta adanya perbedaan geografis di beberapa wilayahnya, maka menjadi hal yang menarik untuk mengkaji apakah sub sektor pembentuk sektor pertanian merupakan sub sektor basis dan berdaya saing tinggi, sehingga dapat dijadikan dasar dalam merancang strategi pembangunan yang memberikan dampak yang optimal bagi pertumbuhan ekonomi, peningkatan lapangan pekerjaan dan peningkatan kesejahteraan penduduk, mengingat kabupaten ini sangat bergantung dengan sektor pertanian.

Penelitian ini mencoba mengkaji sub sektor basis penyokong sektor pertanian yang memiliki daya saing tinggi di wilayah yang lebih besar (Propinsi Sumatera Utara) sehingga dapat menjadi sektor unggulan yang dapat dikembangkan dalam upaya peningkatan perekonomian daerah.

Tujuan penelitian ini yaitu untuk mengetahui kontribusi dan pertumbuhan sub sektor pembentuk sektor pertanian di Kabupaten Langkat, mengetahui sub sektor basis dan non basis di sektor pertanian di Kabupaten Langkat, mengetahui daya saing dari sub sektor pembentuk sektor pertanian di Kabupaten Langkat dan menentukan sub sektor unggulan pembentuk sektor pertanian di Kabupaten Langkat.

\section{METODE PENELITIAN}

Penelitian ini menggunakan data sekunder yang diperoleh dari Badan Pusat Statistik Kabupaten Langkat tahun 2000-2011, yaitu Data Produk Domestik Regional Bruto (PDRB) atas dasar harga berlaku dan atas dasar harga konstan 2000 di kecamatan-kecamatan di Kabupaten Langkat dan Data Produk Domestik Regional Bruto (PDRB) atas dasar harga berlaku dan atas dasar harga konstan 2000 setiap sektor di Sumatera Utara.

Untuk menjawab permasalahan pada penelitian ini maka digunakan beberapa metode analisis yaitu Analisis Location Quotient (LQ) digunakan untuk menentukan sektor basis dan non basis dalam perekonomian wilayahLangkat Hulu, Langkat Hilir dan Teluk Aru serta Analisis Revealed Comparative Advantage $(R C A)$ digunakan untuk mengetahui daya saing sektor perekonomian wilayah Kabupaten Langkat.

Analisis LQ adalah formula yang digunakan untuk mengetahui sejauh mana tingkat spesialisasi/ konsentrasi sektor-sektor wilayah (Bendavid-Val, 1991: 73; Shaver, 1989: 268, dalam Harun dan Syarw ani, 2006: 21). Formulasinya adalah:

QE Journal |Vol.02 - No.03 - 19 


$$
L Q=\left[\frac{\left({ }^{(i r} / Q_{r}\right)}{\left({ }^{Q_{n r} / Q_{n}}\right)}\right]
$$

dimana:

$\mathrm{Q}_{\text {ir }}=$ NTB ADHK 2000 sektor i Kabupaten Langkat

$\mathrm{Q}_{\mathrm{r}}=$ PDRB ADHK 2000 Kabupaten Langkat

$\mathrm{Q}_{\mathrm{nr}}=$ NTB ADHK 2000 sektor i Propinsi Sumatera Utara

$\mathrm{Q}_{\mathrm{n}}=$ PDRB ADHK 2000 Propinsi Sumatera Utara

NTB ADHK 2000 = Nilai Tambah Bruto Atas Dasar Harga Konstan Tahun Dasar 2000

PDRB ADHK 2000 = Produk Domestik Ragional Bruto Atas Dasar Harga Konstan Tahun Dasar 2000

Apabila LQ $>1$, artinya peranan sektor i di Langkat lebih menonjol daripada peranan sektor itu di tingkat propinsi. Atau dengan kata lain sektor itu merupakan sektor basis dan potensial untuk dikembangkan sebagai penggerak perekonomian wilayah tersebut.

Apabila LQ $<1$, artinya peranan sektor i di Langkat lebih kecil daripada peranan sektor itu di tingkat propinsi. Atau dengan kata lain sektor itu bukan merupakan sektor basis dan kurang potensial untuk dikembangkan sebagai penggerak perekonomian wilayah tersebut.

Performa sub sektor pertanian Kabupaten Langkat di pasar Sumatera Utara dapat dilihat dari tingkat keunggulan komparatifnya, dimana dalam hal ini dapat diketahui dengan melakukan analisis RCA. Konsep dasar metode ini adalah bahwa perdagangan antar wilayah sebenarnya menunjukkan keunggulan komparatif yang dimiliki suatu daerah/ negara.

Rumus RCA yang digunakan adalah:

$R C A=\frac{\mathrm{x}_{i} / \mathrm{x}_{t}}{\mathrm{~W}_{i} / W_{t}}$

Dimana:

$X_{i}=$ Nilai ekspor suatu wilayah untuk sektor/sub sektor $\mathrm{i}$

$X_{\mathrm{t}} \quad=$ Nilai total ekspor suatu wilayah

$\mathrm{W}_{\mathrm{i}}=$ Nilai ekspor dunia untuk sektor/sub sektor $\mathrm{i}$

$\mathrm{W}_{\mathrm{t}}=$ Nilai total ekspor dunia

Indeks RCA merupakan perbandingan antara nilai RCA sekarang dengan nilai RCA tahun lalu. Rumus indeks RCA adalah sebagai berikut:

$R C A=\frac{R C A_{t}}{R C A_{t-1}}$

$\mathrm{RCA}_{\mathrm{t}}=$ Nilai RCA tahun ke-(t)

QE Journal |Vol.02 - No.03 - 20 
$\mathrm{RCA}_{\mathrm{t}-1}=$ Nilai RCA tahun ke- $(\mathrm{t}-1)$

Indeks RCA berkisar antara nol sampai tak hingga. Nilai indeks RCA sama dengan satu berarti tidak terjadi kenaikan RCA atau daya saing sektor pertanian sekarang sama dengan tahun lalu.

\section{HASIL DAN PEMBAHASAN}

\section{Analisis LQ (Location Quetion) Sektor dan Sub Sektor Pertanian}

Analisis LQ (Location Quetion) digunakan untuk mengetahui sektor-sektor ekonomi dalam PDRB yang dapat digolongkan ke dalam sektor basis dan non basis. LQ merupakan suatu perbandingan tentang besarnya peranan suatu sektor di Kabupaten Langkat terhadap besarnya peranan sektor tersebut di tingkat Propinsi Sumatera Utara.

Apabila LQ $>1$, artinya peranan sektor itu di Kabupaten lebih menonjol dari pada peranan sektor itu di tingkat Propinsi. Atau dengan kata lain sektor itu merupakan sektor unggulan dan potensial untuk dikembangkan sebagai penggerak perekonomian wilayah tersebut.

Apabila LQ $<1$, artinya peranan sektor itu di Kabupaten lebih kecil daripada peranan sektor itu di tingkat Propinsi. Atau dengan kata lain sektor itu bukan merupakan sektor unggulan dan kurang potensial untuk dikembangkan sebagai penggerak perekonomian wilayah tersebut.

Hasil perhitungan LQ sektor dan sub sektor pertanian (Location Quetion) Kabupaten Langkat dari kurun waktu tahun 2000-2011 pada Tabel 6 menunjukkan bahwa sektor pertanian merupakan sektor basis begitu pula dengan sub sektornya. Sub sektor tanaman bahan makanan dengan nilai LQ sebesar 1,87 merupakan kontribusi dari beberapa komoditi tanaman pangan (padi sawah dan padi ladang), palawija (jagung, ubi kayu, ubi jalar, kedelai, kacang tanah, kacang hijau) serta hortikultura (ketimun, kacang panjang, terong, tomat, kangkung, bayam, cabe, petsai dan semangka).

Sub sektor tanaman perkebunan dengan nilai LQ sebesar 2,18 didominasi oleh tanaman karet, kelapa sawit dan kakao.

Sub sektor peternakan dan hasil-hasilnya memiliki nilai LQ sebesar 1,34 yang didukung oleh komoditas ternak besar (kerbau dan sapi potong), ternak kecil (kambing, domba dan babi) serta unggas (ayam kampung, itik dan ayam ras petelur).

Sub sektor kehutanan dengan nilai LQ 8,59 yang merupakan sektor basis dengan nilai LQ tertinggi di sektor pertanian yaitu sebesar 8,59 yang ditopang oleh komoditas hasil hutan log rimba dan kayu gergajian.

QE Journal |Vol.02 - No.03 - 21 
Sub sektor perikanan dengan nilai LQ 2,83 didukung oleh kegiatan tangkap dan budidaya ikan.

Tabel 1. Hasil Perhitungan Location Quotient (LQ) Kabupaten Langkat Tahun 2001-2011

\begin{tabular}{|c|c|c|c|c|c|c|c|c|c|c|c|c|c|}
\hline $\begin{array}{c}\text { LAP. } \\
\text { USAHA }\end{array}$ & 2000 & 2001 & 2002 & 2003 & 2004 & 2005 & 2006 & 2007 & 2008 & 2009 & 2010r) & $\left.2011^{*}\right)$ & $\begin{array}{c}\text { LQ } \\
\text { Rata- } \\
\text { rata }\end{array}$ \\
\hline $\begin{array}{l}\text { PERTANIAN } \\
\text { a. TB. }\end{array}$ & 2,14 & 2,23 & 2,20 & 2,33 & 2,34 & 2,36 & 2,52 & 2,47 & 2,42 & 2,40 & 2,43 & 2,51 & 2,36 \\
\hline $\begin{array}{l}\text { Makanan } \\
\text { b. T.Perke- }\end{array}$ & 1,63 & 1,67 & 1,61 & 1,74 & 1,90 & 1,85 & 1,99 & 2,00 & 1,99 & 1,99 & 2,00 & 2,05 & 1,87 \\
\hline $\begin{array}{l}\text { bunan } \\
\text { c. Peternakan }\end{array}$ & 2,03 & 2,25 & 2,18 & 2,23 & 2,06 & 2,16 & 2,27 & 2,17 & 2,13 & 2,17 & 2,25 & 2,32 & 2,18 \\
\hline & 1,22 & 1,16 & 1,26 & 1,23 & 1,33 & 1,40 & 1,49 & 1,49 & 1,40 & 1,39 & 1,41 & 1,33 & 1,34 \\
\hline d. Kehutan & 7,17 & 7,00 & 7,33 & 7,68 & 7,98 & 8,54 & 9,53 & 9,56 & 9,65 & 9,22 & 9,41 & 10,06 & 8,59 \\
\hline e. Perikanan & 2,76 & 2,78 & 2,79 & 2,96 & 3,07 & 2,90 & 2,97 & 2,95 & 2,76 & 2,62 & 2,57 & 2,77 & 2,83 \\
\hline
\end{tabular}

\section{Analisis RCA (Revealed Comparative Advantage) Sektor dan Sub Sektor Pertanian}

RCA merupakan salah satu metode yang dapat digunakan untuk mengetahui keunggulan komparatif suatu wilayah (negara, propinsi dan lain-lain). Pada dasarnya metode ini mengukur kinerja suatu komoditi tertentu dengan ekspor total suatu tempat dibandingkan dengan pangsa komiditi tertentu dalam perdagangan dunia. Namun karena terbatasnya data ekspor komoditas/sub sektor/ sektor pertanian maka dalam penelitian ini digunakan nilai tambah sektor/ sub sektor, karena pada dasarnya untuk mengukur keunggulan komparatif suatu daerah dapat menggunakan berbagai variabel seperti nilai tambah bruto, jumlah tenaga kerja, produksi komoditas, dan lain-lain.

Rumus RCA yang digunakan adalah:

Dimana:

$$
R C A=\frac{\mathrm{X}_{i} / \mathrm{X}_{t}}{\mathrm{~W}_{i} / W_{t}}
$$

$\mathrm{X}_{\mathrm{i}} \quad=$ Nilai NTB Kabupaten Langkat untuk sektor/sub sektor i

$X_{t}=$ Nilai PDRB Kabupaten Langkat

$\mathrm{W}_{\mathrm{i}}=$ Nilai NTB Propinsi Sumatera Utara sektor/sub sektor i

$\mathrm{W}_{\mathrm{t}}=$ Nilai PDRB Propinsi Sumatera Utara 
Indeks RCA merupakan perbandingan antara nilai RCA sekarang dengan nilai RCA tahun lalu. Rumus indeks RCA adalah sebagai berikut:

RCA $=$ Nilai RCA tahun ke-( $\mathrm{t})$

$$
R C A=\frac{R C A_{t}}{R C A_{t-1}}
$$

$\mathrm{RCA}_{\mathrm{t}-1}=$ Nilai RCA tahun ke- $(\mathrm{t}-1)$

Indeks RCA berkisar antara nol sampai tak hingga. Nilai indeks RCA sama dengan satu berarti tidak terjadi kenaikan RCA atau daya saing sektor pertanian sekarang sama dengan tahun lalu.

Apabila diperhatikan pada Tabel 1, dalam kurun waktu tahun 2001-2011, terlihat bahwa indeks RCA untuk sektor/ sub sektor pertanian Kabupaten Langkat memiliki nilai di atas 1 . Hal ini menunjukkan bahwa sektor dan sub sektor pertanian Kabupaten Langkat memiliki daya saing yang tinggi di pasar Sumatera Utara untuk sub sektor yang sama. Sub sektor kehutanan memiliki nilai RCA tertinggi selama kurun waktu 2001-2011 dengan rata-rata 1,03; kemudian diikuti dengan sub sektor tanaman bahan makanan $(1,02)$, tanaman perkebunan $(1,01)$, peternakan dan hasil-hasilnya $(1,01)$ dan perikanan $(1,00)$.

Meski secara rata-rata, semua sub sektor pertanian Kabupaten Langkat memiliki nilai di atas 1, namun dalam kurun waktu 2001-2011 daya saingnya cenderung berfluktuatif, hanya sub sektor tanaman bahan makanan yang cenderung stabil daya saingnya pada tahun 2006-2011. Berfluktuatifnya daya saing sub sektor pertanian hendaknya menjadi perhatian pemerintah daerah Kabupaten Langkat agar lebih optimal dalam upaya pengembangan kegiatan pertanian yang merupakan tulang punggung perekonomian kabupatennya.

Tabel 2. Indeks RCA (Revealed Comparative Advantage) Sektor dan Sub Sektor Pertanian Kabupaten Langkat Tahun 2001-2011

\begin{tabular}{|c|c|c|c|c|c|c|c|c|c|c|c|c|}
\hline LAPANGAN USAHA & 2001 & 2002 & 2003 & 2004 & 2005 & 2006 & 2007 & 2008 & 2009 & 2010r) & $2011 *)$ & $\begin{array}{c}\text { Indeks } \\
\text { RCA } \\
\text { Rata- } \\
\text { rata }\end{array}$ \\
\hline $\begin{array}{l}\text { PERTANIAN } \\
\text { a. Tanaman Bahan }\end{array}$ & 1,04 & 0,99 & 1,06 & 1,00 & 1,01 & 1,06 & 0,98 & 0,98 & 0,99 & 1,01 & 1,03 & 1,02 \\
\hline $\begin{array}{l}\text { Makanan } \\
\text { b. Tanaman }\end{array}$ & 1.02 & 0,96 & 1,09 & 1,09 & 0,97 & 1,08 & 1,00 & 1,00 & 1,00 & 1,01 & 1,02 & 1,02 \\
\hline $\begin{array}{l}\text { Perkebunan } \\
\text { c. Peternakan dan }\end{array}$ & 1,11 & 0,97 & 1,02 & 0,92 & 1,05 & 1,05 & 0,96 & 0,98 & 1,02 & 1,04 & 1,03 & 1,01 \\
\hline Hasil-hasilnya & 0,95 & 1,09 & 0,98 & 1,08 & 1,05 & 1,06 & 1,00 & 0,94 & 0,99 & 1,01 & 0,94 & 1,01 \\
\hline d. Kehutan & 0,98 & 1,05 & 1,05 & 1,04 & 1,07 & 1,12 & 1,00 & 1,01 & 0,95 & 1,02 & 1,07 & 1,03 \\
\hline e. Perikanan & 1,01 & 1,00 & 1,06 & 1,04 & 0,94 & 1,02 & 0,99 & 0,94 & 0,95 & 0,98 & 1,08 & 1,00 \\
\hline
\end{tabular}




\section{Analisis Sub Sektor Tanaman Bahan Makanan}

Kontribusi sub sektor tanaman bahan makanan terhadap nilai tambah sektor pertanian Kabupaten Langkat rata-ratanya sebesar 28 persen dan berada pada urutan ke dua setelah sub sektor tanaman perkebunan. Laju pertumbuhan sub sektor ini rata-rata sebesar 5,4 persen per tahun dan lebih tinggi dibandingkan rata-rata laju pertumbuhan di tingkat Provinsi.

Nilai LQ sub sektor bahan makanan menunjukkan nilai lebih besar dari 1, yaitu 1,87 yang berarti sub sektor ini masuk ke dalam sub sektor basis. Perkembangan nilai LQ sub sektor ini selama periode penelitian berfluktuatif dimana secara umum mengalami peningkatan seperti ditunjukkan Gambar 1.

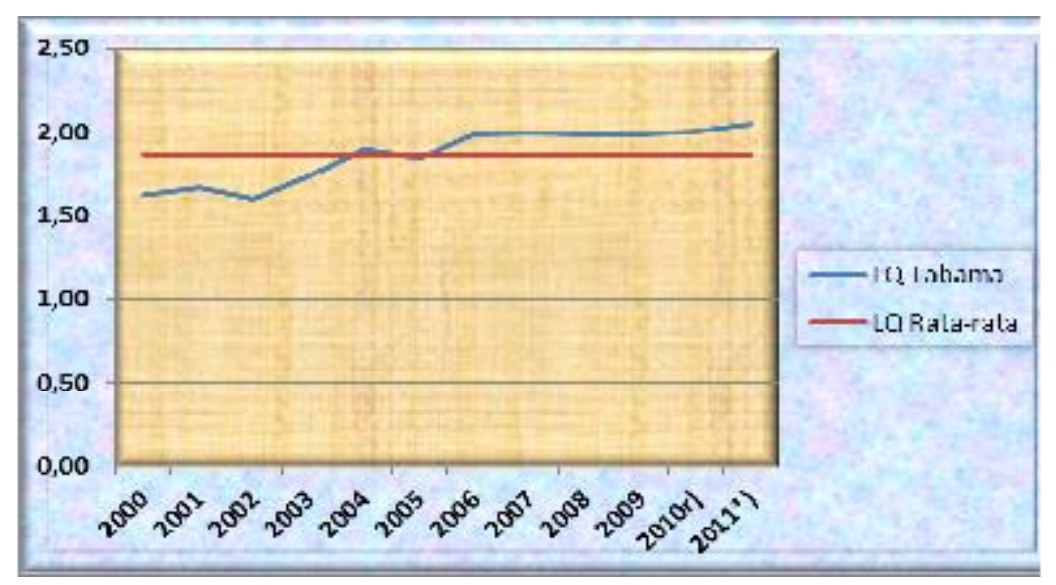

Gambar 1. Perkembangan LQ Sub Sektor Tanaman Bahan Makanan

Hasil analisis RCA sub sektor tanaman bahan makanan, rata-rata nilai indeks RCA sub sektor ini selama periode penelitian menunjukkan nilai yang lebih besar dari 1 , yaitu 1,02 yang berarti sub sektor ini memiliki daya saing yang tinggi di tingkat Propinsi Sumatera Utara.

Berdasarkan analisis sub sektor tanaman bahan makanan, menunjukkan bahwa sub sektor ini dapat digolongkan ke dalam sektor unggulan yang memiliki daya saing yang tinggi di Propinsi Sumatera Utara.

Sub sektor tanaman bahan makanan dapat ditinjau dari jumlah produksi padi, palawija dan hortikultura. Jumlah produksi padi di Kabupaten Langkat didominasi oleh tanaman padi sawah adalah 400.273 ton dengan luas panen 67.155 Ha pada tahun 2010 dimana tanaman ini di produksi hampir di seluruh kecamatan. Sementara jumlah tanaman padi ladang hanya memproduksi sekitar 1.210 ton dengan luas panen $389 \mathrm{Ha}$ dimana hanya beberapa kecamatan saja yang

QE Journal |Vol.02 - No.03 - 24 
mengusahakannya yaitu Kecamatan Bahorok, Salapian, Sei Bingai, Kuala dan Selesai pada tahun 2010.

Sementara itu, untuk produksi tanaman palawija banyak didominasi oleh tanaman jagung sebanyak 92 persen atau 131.033 ton sedangkan komoditas lainnya tidak mencapai 5 persen pada 2010. Besarnya produksi tanaman jagung karena ada 22 kecamatan yang memproduksi jagung dan hanya 1 kecamatan yang tidak mengusahakannya yaitu Kecamatan Babalan. Sedangkan untuk komoditas tanaman palawija yang lain hanya beberapa kecamatan saja yang mengusahakannya.

Sementara itu tanaman hortikultura pada tahun 2011 didominasi oleh tanaman semangka dengan luas panen 345 Ha dan produksinya 7.138 ton sedangkan tanaman hortikultura lainnya produksinya tidak mencapai 2.000 ton. Salah satu faktor keberhasilan tanaman pangan di Kabupaten Langkat disebabkan ketersediaan dan pemanfaatan lahan yang sangat luas.

Pada tahun 2011, kondisi lahan pertanian yang meliputi lahan sawah maupun bukan sawah seluas 312.175 hektar, dimana lahan bukan sawah seluas 271.739 hektar dan lahan sawah seluas 40.436 hektar. Sementara lahan bukan pertanian yang peruntukannya untuk rumah, bangunan dan halaman sekitarnya, hutan Negara, rawa-rawa (tidak ditanami) dan lainnya ada seluas 314.154 hektar. Jumlah lahan bukan pertanian cendrung bertambah karena alih fungsi lahan akibat pertumbuhan jumlah penduduk sehingga lahan-lahan pertanian digunakan untuk mendirikan bangunan tempat tinggal maupun kawasan pengembangan industri (Aritonang: 2011, halaman 38-39).

Pergeseran fungsi lahan untuk jangka panjang perlu menjadi perhatian pemerintah karena seperti diketahui bahwa hasil produksi lahan tersebut merupakan komoditas untuk makanan pokok masyarakat sehingga apabila terus terjadi pengurangan luas lahan pertanian akan mempengaruhi ketersediaan makanan pokok masyarakat. Tentunya program intensifikasi lahan maupun pembangunan sistem teknologi pertanian perlu dioptimalkan dan diawasi pelaksanaannya.

\section{Analisis Sub Sektor Tanaman Perkebunan}

Kontribusi sub sektor tanaman perkebunan terhadap nilai tambah sektor pertanian Kabupaten Langkat rata-ratanya sebesar 36,6 persen dan merupakan sub sektor yang memiliki kontribusi terbesar. Laju pertumbuhan sub sektor ini rata-rata sebesar 3,6 persen per tahun dan lebih rendah dibandingkan rata-rata laju pertumbuhan di tingkat Provinsi.

Nilai LQ sub sektor tanaman perkebunan menunjukkan nilai lebih besar dari 1, yaitu 2,18 yang berarti sub sektor ini masuk ke dalam sub sektor basis. 
Perkembangan nilai LQ sub sektor ini selama periode penelitian berfluktuatif dimana secara umum mengalami peningkatan seperti ditunjukkan Gambar 2 sejak tiga tahun terakhir.

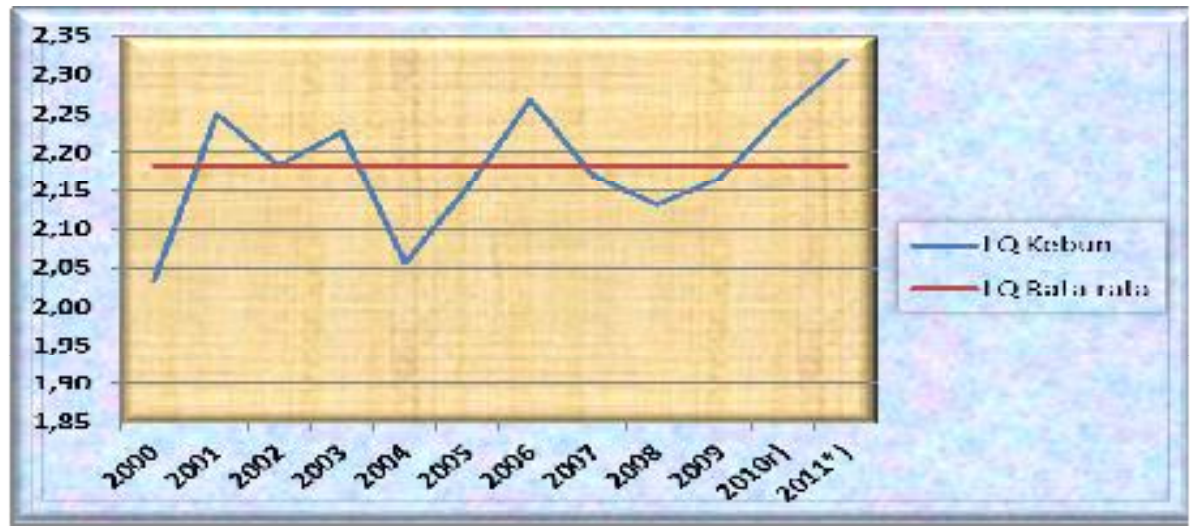

Gambar 2. Perkembangan LQ Sub Sektor Tanaman Perkebunan

Hasil analisis RCA sub sektor tanaman perkebunan, rata-rata nilai indeks RCA sub sektor ini selama periode penelitian menunjukkan nilai yang lebih besar dari 1, yaitu 1,01 yang berarti subsektor ini memiliki daya saing yang tinggi di tingkat Propinsi Sumatera Utara.

Berdasarkan analisis sub sektor tanaman perkebunan, menunjukkan bahwa sub sektor ini dapat digolongkan ke dalam sektor unggulan yang memiliki daya saing yang tinggi di Propinsi Sumatera Utara.

Komoditas tanaman perkebunan rakyat paling utama di Kabupaten Langkat adalah tanaman kelapa sawit dengan produksi tahun 2010 sebesar 611.391 ton dimana telah terjadi peningkatan luas lahan perkebunan sawit dari tahun 2007 seluas 41.424 Ha menjadi 41.542 Ha pada tahun 2010. Perkebunan sawit diusahakan di seluruh kecamatan di Kabupaten Langkat. Menurut Dinas Perkebunan dan Kehutanan Kabupaten Langkat, Perkebunan Sawit di Langkat didominasi oleh perusahaan negara $(44.974 \mathrm{Ha})$ dan perusahaan rakyat $(41.542$ Ha).

Sementara itu, komoditas perkebunan lainnya yang cukup besar produksinya dan diusahakan di seluruh kecamatan di Kabupaten Langkat adalah

tanaman karet perkebunan rakyat dengan besar produksi 59.586 ton pada tahun 2010. Perkebunan karet tanaman rakyat juga mengalami perluasan lahan dari 41.772 Ha pada tahun 2007 menjadi 42.056 Ha pada tahun 2010.

QE Journal |Vol.02 - No.03 - 26 


\section{Analisis Sub Sektor Peternakan}

Kontribusi sub sektor peternakan terhadap nilai tambah sektor pertanian Kabupaten Langkat rata-ratanya sebesar 5,5 persen yang juga merupakan sub sektor dengan kontribusi terkecil. Laju pertumbuhan sub sektor ini rata-rata sebesar 4,3 persen per tahun dan lebih tinggi dibandingkan rata-rata laju pertumbuhan di tingkat Provinsi.

Nilai LQ sub sektor peternakan menunjukkan nilai lebih besar dari 1, yaitu 1,34 yang berarti sub sektor ini masuk ke dalam sub sektor basis. Perkembangan nilai LQ sub sektor ini selama periode penelitian berfluktuatif dimana secara umum mengalami penurunan seperti ditunjukkan Gambar 3.

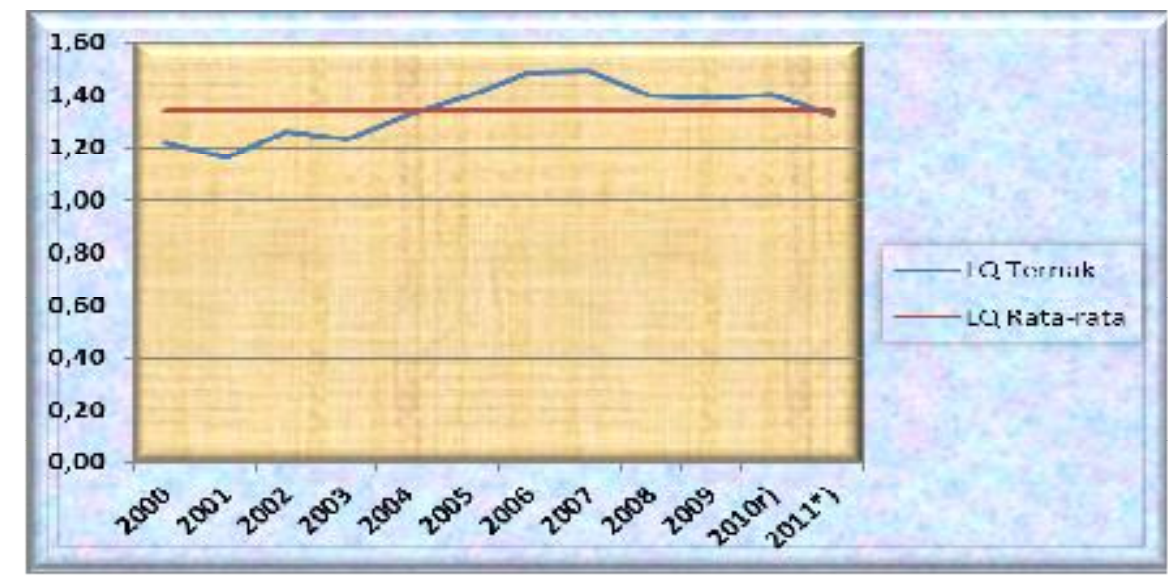

Gambar 3. Perkembangan LQ Sub Sektor Peternakan

Hasil analisis RCA sub sektor peternakan, rata-rata nilai indeks RCA sub sektor ini selama periode penelitian menunjukkan nilai yang lebih besar dari 1, yaitu 1,01 yang berarti sub sektor ini memiliki daya saing yang tinggi di tingkat Propinsi Sumatera Utara.

Berdasarkan analisis sub sektor peternakan, menunjukkan bahwa sub sektor ini dapat digolongkan ke dalam sektor unggulan yang memiliki daya saing yang tinggi di Propinsi Sumatera Utara.

Hasil produksi sub sektor peternakan berupa daging, telur serta susu segar banyak diusahakan oleh rakyat. Populasi ternak di Kabupaten Langkat dikelompokkan menjadi:

1. Ternak besar, meliputi sapi potong, kerbau, kuda dan sapi perah

2. Ternak kecil, meliputi: kambing, domba dan babi 
3. Ternak unggas, meliputi: ayam ras (petelur dan pedaging), ayam kampong dan itik lokal.

Pemeliharaan ternak kerbau terdapat hampir di setiap kecamatan kecuali Kecamatan Kutambaru. Sedangkan ternak kuda hanya dijumpai di Kecamatan Salapian dan Sei Bingai. Demikian pula sapi perah hanya terdapat di Kecamatan Serapit, Binjai dan Stabat.

Tabel 3. Populasi Ternak Besar Kabupaten Langkat Menurut Jenis Ternak (Ekor) Tahun 2008-2011

\begin{tabular}{ccccc}
\hline \multirow{2}{*}{ Tahun } & \multicolumn{5}{c}{ Ternak Besar } \\
\cline { 2 - 5 } & Sapi Potong & Kerbau & Kuda & Sapi Perah \\
\hline $\mathbf{2 0 0 8}$ & 114.812 & 10.623 & 25 & 1255 \\
$\mathbf{2 0 0 9}$ & 128.442 & 11.921 & 27 & 1727 \\
$\mathbf{2 0 1 0}$ & 136.370 & 12.116 & 34 & 75 \\
$\mathbf{2 0 1 1}$ & 150.033 & 3.348 & 34 & 33 \\
\hline
\end{tabular}

Sumber: Kabupaten Langkat Dalam Angka 2012

Pada tabel 3 di atas terlihat bahwa populasi sapi potong terus mengalami peningkatan setiap tahunnya dan di tahun 2011 meningkat sekitar 10 persen dari tahun 2010. Sementara itu, populasi kerbau, kuda dan sapi perah cenderung menurun jumlahnya. Bahkan populasi kuda dan sapi perah berkurang lebih dari 50 persen pada tahun 2011 dibandingkan tahun sebelumnya.

Tabel 4. Populasi Ternak Kecil Kabupaten Langkat Menurut Jenis Ternak (Ekor) Tahun 2008-2011

\begin{tabular}{cccc}
\hline \multirow{2}{*}{ Tahun } & \multicolumn{3}{c}{ Ternak Kecil } \\
\cline { 2 - 4 } & Kambing & Domba & Babi \\
\hline $\mathbf{2 0 0 8}$ & 114.492 & 116.589 & 12.674 \\
$\mathbf{2 0 0 9}$ & 128.579 & 125.113 & 12.491 \\
$\mathbf{2 0 1 0}$ & 131.677 & 124.278 & 12.266 \\
$\mathbf{2 0 1 1}$ & 137.532 & 127.913 & 13.440 \\
\hline
\end{tabular}

Sumber: Kabupaten Langkat Dalam Angka 2012

Meskipun jumlah ternak besar cenderung menurun populasinya, namun pertumbuhan populasi ternak kecil cukup tinggi. Hal ini menggambarkan bahwa ternak kecil merupakan komoditas sub sektor peternakan yang paling banyak diminati masyarakat untuk diusahakan.

Begitu pula pada Tabel 5, terlihat hal senada dengan kondisi ternak kecil. Ternak unggas juga memiliki kecendrungan meningkat pertambahan populasinya dikarenakan hasil produksi dari ternak unggas tersebut (berupa daging dan telur) dapat dijadikan alternatif pengganti ikan.

QE Journal |Vol.02 - No.03 - 28 
Tabel 5. Populasi Ternak Unggas Kabupaten Langkat Menurut Jenis Ternak (Ekor) Tahun 2008-2011

\begin{tabular}{ccccc}
\hline \multirow{2}{*}{ Tahun } & \multicolumn{2}{c}{ Ayam Ras } & Ayam Kampung & Itik Lokal \\
\cline { 2 - 3 } & Petelur & Pedaging & & \\
\cline { 2 - 3 } 2008 & 697.300 & 3.330 .098 & 670.230 & 150.725 \\
2009 & 800.447 & 2.668 .349 & 771.642 & 173.227 \\
2010 & 819.100 & 2.861 .753 & 798.396 & 176.783 \\
2011 & 808.124 & 2.885 .316 & 822.548 & 179.930 \\
\hline
\end{tabular}

Sumber: Kabupaten Langkat Dalam Angka 2012

\section{Analisis Sub Sektor Kehutanan}

Kontribusi sub sektor kehutanan terhadap nilai tambah sektor pertanian Kabupaten Langkat rata-ratanya sebesar 17,4 persen selama periode penelitian dan berada pada urutan ke tiga setelah sub sektor tanaman perkebunan dan tanaman bahan makanan. Laju pertumbuhan sub sektor ini rata-rata sebesar 8,9 persen per tahun dan lebih tinggi dibandingkan rata-rata laju pertumbuhan di tingkat Provinsi.

Nilai LQ sub sektor kehutanan menunjukkan nilai lebih besar dari 1, yaitu 8,59 yang berarti sub sektor ini masuk ke dalam sub sektor basis. Perkembangan nilai LQ sub sektor ini selama periode penelitian berfluktuatif dimana secara umum mengalami peningkatan seperti ditunjukkan Gambar 5.

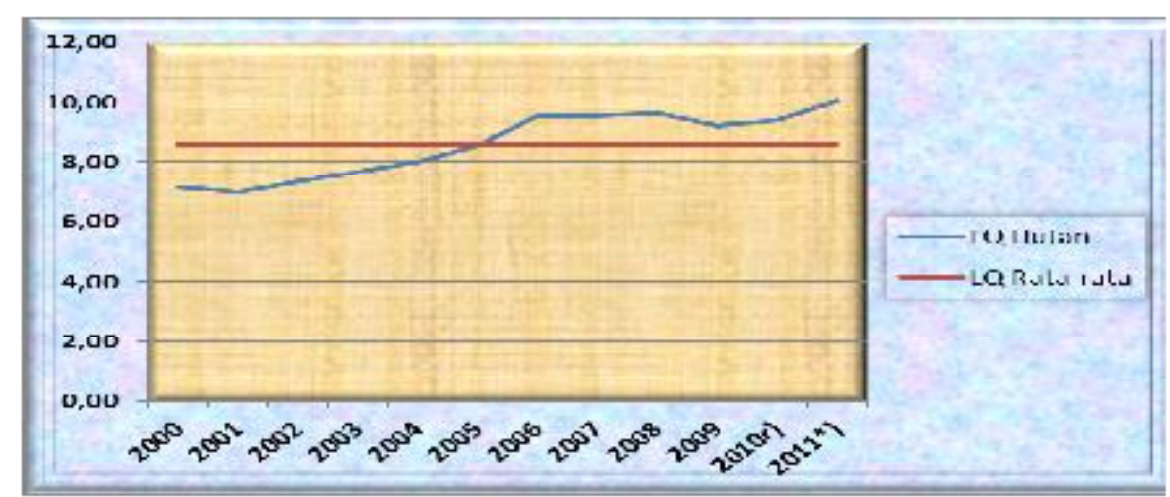

Gambar 5. Perkembangan LQ Sub Sektor Kehutanan

Hasil analisis RCA sub sektor kehutanan, rata-rata nilai indeks RCA sub sektor ini selama periode penelitian menunjukkan nilai yang lebih besar dari 1, yaitu 1,03

QE Journal |Vol.02 - No.03 - 29 
yang berarti sub sektor ini memiliki daya saing yang tinggi di tingkat Propinsi Sumatera Utara.

Berdasarkan analisis sub sektor kehutanan, menunjukkan bahwa sub sektor ini dapat digolongkan ke dalam sektor unggulan yang memiliki daya saing yang tinggi di Propinsi Sumatera Utara.

Hasil utama sub sektor kehutanan adalah kayu dan hasil ikutannya adalah arang, kayu bakar, bambu, damar, rotan dan lainnya. Berdasarkan data dari Dinas Kehutanan dan Perkebunan Kabupaten Langkat tahun 2011 hanya ada dua jenis hasil hutan yaitu kayu gelondongan dengan jumlah produksi $66.036,80 \mathrm{~m}^{3}$ dan kayu olahan lainnya $39.706,54 \mathrm{~m}^{3}$.

Tabel 6. Produksi Hasil Hutan Kabuapten Langkat Menurut Jenis Komoditas Tahun 2011

\begin{tabular}{|c|c|c|c|c|c|}
\hline \multirow{2}{*}{ Jenis Komoditas } & \multirow{2}{*}{ Satuan } & \multicolumn{4}{|c|}{ Produksi } \\
\hline & & 2008 & 2009 & 2010 & 2011 \\
\hline 1. Arang & Ton & $8.866,30$ & $8.902,64$ & $7.423,50$ & - \\
\hline 2. Kayu Gelondongan & $\mathrm{m}^{3}$ & $66.050,84$ & $32.700,12$ & $65.983,40$ & $66.036,80$ \\
\hline 3.Kay u Campuran & $\mathrm{m}^{3}$ & - & - & - & - \\
\hline 4.Lainnya (kay u olahan) & - & $27.055,96$ & $33.147,62$ & $36.282,67$ & $39.706,54$ \\
\hline
\end{tabular}

Sumber:Kabupaten Langkat Dalam Angka 2012

Komoditas hasil produksi sub sektor kehutanan memiliki hubungan yang erat dengan sektor konstruksi sehingga keterkaitannya berpengaruh pada proses pembangunan nasional. Oleh karena itu perlu dijaga ketersediaan hasil hutan dengan menggalakkan program reboisasi.

\section{Analisis Sub Sektor Perikanan}

Kontribusi sub sektor perikanan terhadap nilai tambah sektor pertanian Kabupaten Langkat rata-ratanya sebesar 12,5 persen dan lebih besar kontribusinya dari sub sektor peternakan. Laju pertumbuhan sub sektor ini rata-rata sebesar 0,8 persen per tahun dan lebih rendah dibandingkan rata-rata laju pertumbuhan di tingkat Provinsi.

Nilai LQ sub sektor perikanan menunjukkan nilai lebih besar dari 1, yaitu 2,83 yang berarti sub sektor ini masuk ke dalam sub sektor basis. Perkembangan nilai LQ sub sektor ini selama periode penelitian berfluktuatif dimana secara umum mengalami peningkatan seperti ditunjukkan Gambar 6.

QE Journal |Vol.02 - No.03 - 30 


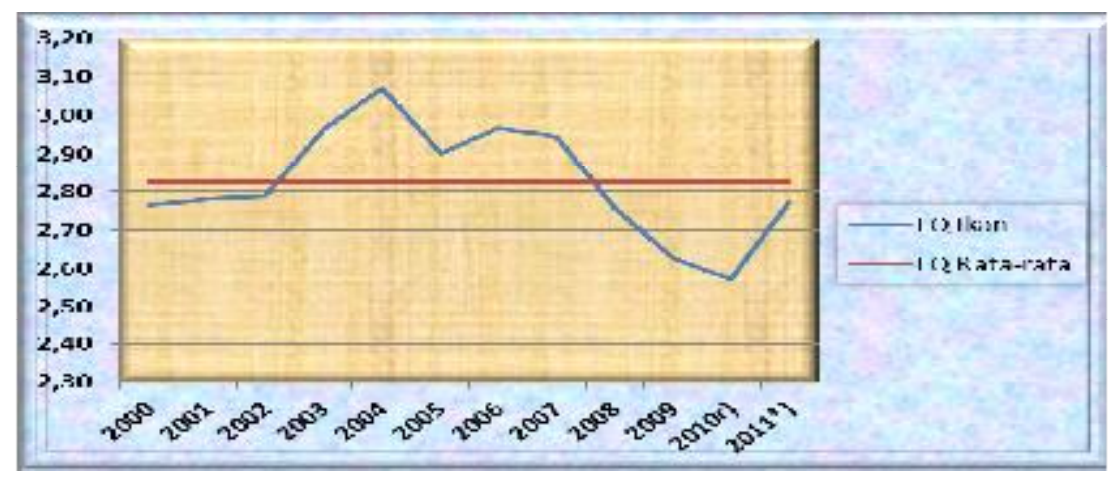

Gambar 6. Perkembangan LQ Sub Sektor Perikanan

Hasil analisis RCA sub sektor perikanan, rata-rata nilai indeks RCA sub sektor ini selama periode penelitian menunjukkan nilai sama dengan 1 yang berarti sub sektor ini memiliki daya saing yang sama dengan sub sektor yang sama di tingkat Propinsi Sumatera Utara atau dengan kata lain tidak ada peningkatan daya saing.

Berdasarkan analisis sub sektor perikanan, menunjukkan bahwa sub sektor ini dapat digolongkan ke dalam sektor unggulan yang daya saingnya sama dengan sub sektor perikanan yang ada di Propinsi Sumatera Utara.

Kegiatan penangkapan dan budidaya ikan di Kabupaten Langkat lebih banyak dilakukan di perairan laut dan air payau karena kabupaten ini berbatasan langsung dengan Selat Malaka yang menyediakan areal yang cukup potensial untuk pengembangan sub sektor perikanan. Beberapa Kecamatan yang yang merupakan pusat kegiatan perikanan laut yaitu Pangkalan Susu, Sei Lepan, Brandan Barat, Babalan, Gebang, Tanjung Pura dan Secanggang.

Sektor pertanian sebagai basis perekonomian Kabupaten Langkat hendaknya tetap menjadi perhatian dalam pengembangannya untuk peningkatan efektivitas pembangunan ekonomi. Apalagi dalam sistem otonomi daerah yang sedang berlangsung saat ini hendakny a pemerintah daerah dapat lebih kreatif dan mampu membuat perencanaan dalam mengambil keputusan yang berkualitas dalam rangka peningkatan kesejahteraan rakyat sebagai tolak ukur keberhasilan pembangunan ekonomi.

Prioritas pembangunan ekonomi di sektor dan sub sektor pertanian haruslah didasarkan pada sektor dan sub sektor unggulan, tidak hanya di dasarkan pada sumber daya alam yang dimiliki, tetapi juga juga teknologi dan kualitas SDM serta tetap memperhatikan aspek lingkungan agar komoditas yang dihasilkan memiliki daya saing tinggi . 
Keberhasilan pembangunan di sektor pertanian akan berpengaruh pada sektor lainnya serta dapat menyerap tenaga kerja dan menambah pendapatan masyarakat dalam upaya mengurangi pengangguran.

Analisis penentuan sektor basis/ unggulan dan penentuan daya saingnya dibutuhkan sebagai dasar dalam perencanaan pembangunan dan mengalokasikan anggaran yang tepat di Kabupaten Langkat, sehingga kebijakan yang dilakukan pemerintah daerah dapat tepat guna menggerakkan sektor dan sub sektor pertanian.

\section{SIMPULAN DAN SARAN}

\section{Simpulan}

Sektor pertanian merupakan tulang punggung perekonomian Kabupaten Langkat karena lebih dari 50 persen perekonomiannya ditopang oleh sektor ini dengan pertumbuhan yang terus meningkat selama 3 tahun terakhir.

Sub sektor tanaman perkebunan dan tanaman bahan makanan merupakan sub sektor pembetuk sektor pertanian yang memiliki kontribusi paling besar serta pertumbuhannya terus meningkat selama beberapa tahun terakhir. Sementara kontribusi sub sektor lainnya tidak mencapai 20 persen.

Hasil analisis LQ (Location Quetiont) menunjukkan bahwa sektor pertanian beserta sub sektor pembentuknya (sub sektor tanaman bahan makanan, tanaman perkebunan, perkebunan, kehutanan dan perikanan) merupakan sektor/sub sektor basis $(\mathrm{LQ}>1)$

Hasil analisis RCA menunjukkan bahwa sektor pertanian dan sub sektor pembentuknya (sub sektor tanaman bahan makanan, tanaman perkebunan, peternakan dan kehutanan) memiliki daya saing yang tinggi di pasar Sumatera Utara (nilai Indeks RCA > 1). Sementara itu sub sektor perikanan Kabupaten Langkat memiliki daya saing yang sama dengan sub sektor perikanan di pasar Sumatera Utara (nilai Indeks RCA $=1$ )

Berdasarkan hasil perhitungan dari kedua analisis tersebut menunjukkan bahwa sektor/sub sektor unggulan dengan kriteria tergolong ke dalam sektor/ sub sektor basis dan berdaya saing tinggi yaitu sektor pertanian dengan sub sektor pembentuknya (sub sektor tanaman bahan makanan, tanaman perkebunan, peternakan dan kehutanan).

\section{Saran}

Pemerintah Daerah Kabupaten Langkat hendaknya memperhatikan potensi daerahnya yang tercermin dalam sektor dan sub sektor unggulan dalam 
melakukan perancanaan pembangunan guna meningkatkan perekonomian daerah menuju kesejahteraan rakyat.

Sektor pertanian sebagai sektor unggulan yang ditopang oleh sub sektor unggulan (tanaman bahan makanan, tanaman perkebunan, kehutanan dan peternakan) perlu menjadi prioritas dalam perencanaan pembangunan sehingga dapat membuka lapangan pekerjaan bagi masyarakat sekitar. Selain itu pemerintah daerah perlu membantu usaha-usaha kecil untuk membangun ekonomi kerakyatan di sub sektor tersebut, mendatangkan investor untuk menanamkan modalnya dan melakukan transfer teknologi sehingga dengan sendirinya sumber daya manusia (SDM) dapat meningkat pula kualitasnya.

Sub sektor perikanan hendaknya tetap mendapat perhatian dalam pengembangannya guna meningkatkan daya saingnya di pasar Sumatera Utara sehingga dapat menjadi sektor unggulan.

\section{DAFTAR PUSTAKA}

Abimanyu, A., dan Megantara, A. 2009. Era Baru Kebijakan Fiskal: Pemikiran, Konsep dan Implementasi. Jakarta: Penerbit Buku Kompas

Adisasmita, Rahardjo. 2008. Pengembangan Wilayah : Konsep dan Teori. Yogyakarta: Graha Ilmu

Arsjad, Lincolin. 1999. Ekonomi Pembangunan. Yogyakarta : Penerbit Sekolah Tinggi Ilmu Ekonomi, YKPN.

Balitbang Propinsi Sumatera Utara. (Desember 2006). Kajian Terhadap Perkembangan Kabupaten Mandailing Natal, Toba Samosir, Samosir dan Pak-Pak Bharat Sebagai Hasil Pemekaran. Jurnal INOVASI, 3 (4), 13-23.

Bancin, Roy Efraim. 2011. Analisa Penentuan Sektor Unggulan Pertekonomian Wilayah Kabupaten Pak pak Barat. [Tesis\}. Medan: USU

Bank Indonesia. Kajian Ekonomia Regional Sumatera Utara Triwulan IV-2011. Medan . Kajian Ekonomia Regional Sumatera Utara Triwulan I-2012. Medan

BPS Kabupaten Langkat. Analisis Ekonomi Makro Kabupaten Langkat. 2012.

. Kabupaten Langkat Dalam Angka 2012.

. Kabupaten Langkat Dalam Angka 2011.

. Statistik Daerah Kabupaten Langkat. 2011.

BPS Propinsi Sumatera Utara. Beberapa Edisi. PDRB Pripinsi Sumatera Utara Menurut Kabupaten Kota.

QE Journal |Vol.02 - No.03 - 33 
Elmi, Bachrul. (Maret 2003). Studi Peningkatan Ekonomi dan Keuangan Kabupaten Lampung Utara Tahun 2002. Jurnal Kajian Ekonomi dan Keuangan,7 (1), 81-112.

Fachrurrazy. (2009). Analisis Penentuan Sektor Unggulan Perekonomian Wilayah Kabupaten Aceh Utara Dengan Pendekatan Sektor Pembentuk PDRB. [Tesis]. Medan: Universtas Sumatera Utara

Fadillah, Achmad. 2001. Analisis Daya Saing Komoditas Unggulan Perikanan Tangkap Kabupaten Sukabumi. Bogor: IPB

Fauzi. 2000. Evaluasi atas Pemekaran Kabupaten Sambas dan Kesiapan Kota Administartif Singkawang menjadi Daerah Kota sebagai Pelaksanaan dari UU No. 25/ 1999. [Tesis]. Yogyakarta: UGM.

Firdaus, A.H. 2011. Kinerja Pedagangan Free Trade Area (FTA) ASEAN PLUS THREE Terhadap Perekonomian Indonesia. [Tesis]. Bogor: IPB

Harmantyo, Djoko. April 2007. Pemekaran Daerah dan Konflik Keruangan, Kebijakan Otonomi Daerah dan Implikasinya di Indonesia. MAKARA SAINS, 11 (1), $16-22$.

Harun, U. R. \& Canon, S. Agustus 2006. Analisis LQshift LQshare Untuk Mengukur Dampak Perluasan Kota Terhadap Kinerja Ekonomi Regional (Studi Kasus: Perluasan Kota Manado terhadap PerekonomianWilayah Sulawesi Utara). Jurnal Perencanaan Wilayah dan Kota, 17 (2), 21-40.

Kharisma, Bayu. 2006. Peran Anggaran Pemerintah Daerah dalam Mendorong Pertumbuhan Ekonomi Sebelum dan Sesudah Era Desentralisasi:Pendekatan Model Ekonometrika 1995-2004. [Tesis]. Depok: Universitas Indonesia.

Malian, A.H., dkk. 2005. Prospek Pengembangan Agro Industri Dalam Meningkatkan Daya Saing Dan Ekspor Berdasarkan permintaan Jenis Produk Komoditas Perkebunan Utama.[Laporan Akhir]. Bogor: IPB

Mangun, N. 2007. Analisis Potensi Ekonomi Kabupaten dan Kota di Propisi Sulawesi Tengah. [Tesis]. Semarang: Universitas Diponegoro

Milwan. 2007. Model Pemekaran Wilayah yang Menyejahterakan Masyarakat [Penelitian]. Jakarta: Universitas Terbuka.

Pramudito. 2004. Analisis Daya Saing Minyak Sawit Indonesia di Pasar Cina serta Strategi Pemasarannya [Skripsi]. Fakultas Pertanian, Institut Pertanian Bogor, Bogor

Ramadhan, Adrian. 2009. Analisis Daya Saing Industri Furniture Rotan Indonesia. Bogor : IPB.

QE Journal | Vol.02 - No.03 - 34 
Republik Indonesia, Undang-Undang Republik Indonesia Nomor 32 Tahun 2004 tentang Pemerintahan Daerah.

Undang-Undang Republik Indonesia Nomor 33 Tahun 2004 tentang Perimbangan Keuangan Pemerintah Pusat dan Daerah.

. Nota Keuangan dan RAPBN Tahun Anggaran 2009.

Rizky, M. dan Amalia A. W. 2011. Daya Saing Produk Ekspor Manufaktur Indonesia Dengan Metode RCA Dinamis. Jurnal Perencanaan Pembangunan, 01 (XVII), 12-15.

Salmon, Andean. 2005. Disparitas Reginal dan Transformasi Sektoral di Propinsi Sumatera Utara (1983-2003): Pengaruh Pertumbuhan Ekonomi. [Tesis]. Depok: Universitas Indonesia

Serin, Vildan dan Abdul Kadir Civan. 2008. Revealed Comparative Advantage and Competitiveness: A Case Study for Turkey towards the EU. Journal of Economic and Social Research, 10 (2), 25-41.

Sitorus. R. H. 2006. Identifikasi Sektor Unggulan untuk Mendukung Perencanaan Pembangunan Ekonomi Kabupaten Toba Samosir. Jakarta: STIS.

Sjafrizal, 1997. Pertumbuhan Ekonomi dan Ketimpangan Wilayah-Wilayah Indonesia Bagian Barat. Prisma, LB3S, 3, 27, 28.

Tambunan, T.H. Tulus. 2001. Industrialisasi Di Negara Sedang Berkembang Kasus Indonesia. Ghalia Indonesia, Jakarta.

Tarigan, Robinson. 2007. Ekonomi Regional, Teori dan Aplikasi. Jakarta: PT Bumi Aksara.

Todaro, Michael P. 2000, Pembangunan Ekonomi di Dunia Ketiga. Terjemahan, Edisi Ketujuh. Jakarta : Penerbit Erlangga

QE Journal |Vol.02 - No.03 - 35 